\title{
Front Matter: Volume 9858
}

, "Front Matter: Volume 9858," Proc. SPIE 9858, Advanced Photon Counting Techniques X, 985801 (6 June 2016); doi: 10.1117/12.2231216

SDIE Event: SPIE Commercial + Scientific Sensing and Imaging, 2016, Baltimore, MD, United States 


\title{
PROCEEDINGS OF SPIE
}

\section{Advanced Photon Counting Techniques $X$}

\author{
Mark A. Itzler \\ Joe C. Campbell \\ Editors
}

20-21 April 2016

Baltimore, Maryland, United States

Sponsored and Published by

SPIE 
The papers in this volume were part of the technical conference cited on the cover and title page. Papers were selected and subject to review by the editors and conference program committee. Some conference presentations may not be available for publication. Additional papers and presentation recordings may be available online in the SPIE Digital Library at SPIEDigitallibrary.org.

The papers reflect the work and thoughts of the authors and are published herein as submitted. The publisher is not responsible for the validity of the information or for any outcomes resulting from reliance thereon.

Please use the following format to cite material from these proceedings:

Author(s), "Title of Paper," in Advanced Photon Counting Techniques X, edited by Mark A. Itzler, Joe C. Campbell, Proceedings of SPIE Vol. 9858 (SPIE, Bellingham, WA, 2016) Six-digit Article CID Number.

ISSN: 0277-786X

ISSN: 1996-756X (electronic)

ISBN: 9781510600997

Published by

SPIE

P.O. Box 10, Bellingham, Washington 98227-0010 USA

Telephone +1 3606763290 (Pacific Time) · Fax +1 3606471445

SPIE.org

Copyright (C) 2016, Society of Photo-Optical Instrumentation Engineers.

Copying of material in this book for internal or personal use, or for the internal or personal use of specific clients, beyond the fair use provisions granted by the U.S. Copyright Law is authorized by SPIE subject to payment of copying fees. The Transactional Reporting Service base fee for this volume is $\$ 18.00$ per article (or portion thereof), which should be paid directly to the Copyright Clearance Center (CCC), 222 Rosewood Drive, Danvers, MA 01923. Payment may also be made electronically through CCC Online at copyright.com. Other copying for republication, resale, advertising or promotion, or any form of systematic or multiple reproduction of any material in this book is prohibited except with permission in writing from the publisher. The CCC fee code is 0277-786X/16/\$18.00.

Printed in the United States of America.

Publication of record for individual papers is online in the SPIE Digital Library.

\section{SPIE. DIGITAL}

Paper Numbering: Proceedings of SPIE follow an e-First publication model. A unique citation identifier (CID) number is assigned to each article at the time of publication. Utilization of CIDs allows articles to be fully citable as soon as they are published online, and connects the same identifier to all online and print versions of the publication. SPIE uses a six-digit CID article numbering system structured as follows:

- The first four digits correspond to the SPIE volume number.

- The last two digits indicate publication order within the volume using a Base 36 numbering system employing both numerals and letters. These two-number sets start with 00, 01, 02, 03, 04, $05,06,07,08,09,0 A, 0 B \ldots$ OZ, followed by 10-1Z, 20-2Z, etc. The CID Number appears on each page of the manuscript. 


\title{
Contents
}

\author{
$\checkmark$ Authors \\ vii Conference Committee
}

\section{SINGLE-PHOTON IMAGING}

985805 Quanta image sensor: concepts and progress (Invited Paper) [9858-4]

985809 Development of low read noise high conversion gain CMOS image sensor for photon counting level imaging [9858-8]

\section{SINGLE-PHOTON AVALANCHE DIODE ARRAYS}

9858 OA Silicon technologies for arrays of Single Photon Avalanche Diodes (Best Paper Award) [9858-9]

9858 OB Development of silicon single-photon avalanche diode at Voxtel Inc. [9858-10]

9858 OC High performance compound semiconductor SPAD arrays (Invited Paper) [9858-11]

\section{SINGLE-PHOTON DEVICE INTEGRATION PLATFORMS}

9858 Ol 3D avalanche multiplication in Si-Ge lateral avalanche photodiodes [9858-17]

\section{TIME-CORRELATED SINGLE-PHOTON COUNTING}

9858 0J Wide-field TCSPC-based fluorescence lifetime imaging (FLIM) microscopy (Invited Paper) [9858-18]

$9858 \mathrm{OL}$ Time-Correlated Photon Counting (TCPC) technique based on a photon-number-resolving photodetector [9858-20]

\section{SUPERCONDUCTING NANOWIRE SPDS}

9858 OM Recent advances in superconducting nanowire single photon detectors for single-photon imaging (Invited Paper) [9858-21] 
PHOTON-COUNTING RECEIVERS

$98580 Q \quad$ Characterization of an advanced harmonic subtraction single-photon detection system based on an InGaAs/InP avalanche diode (Invited Paper) [9858-25]

9858 OR Advanced active quenching circuits for single-photon avalanche photodiodes (Invited Paper) [9858-26]

9858 OS Femtosecond photon-counting receiver (Best Paper Award) [9858-27]

9858 OT Low noise, free running, high rate photon counting for space communication and ranging [9858-28] 


\section{Authors}

Numbers in the index correspond to the last two digits of the six-digit citation identifier (CID) article numbering system used in Proceedings of SPIE. The first four digits reflect the volume number. Base 36 numbering is employed for the last two digits and indicates the order of articles within the volume. Numbers start with 00, 01, 02, 03, 04, 05, 06, 07, 08, 09, 0A, 0B...0Z, followed by 10-1Z, 20-2Z, etc.

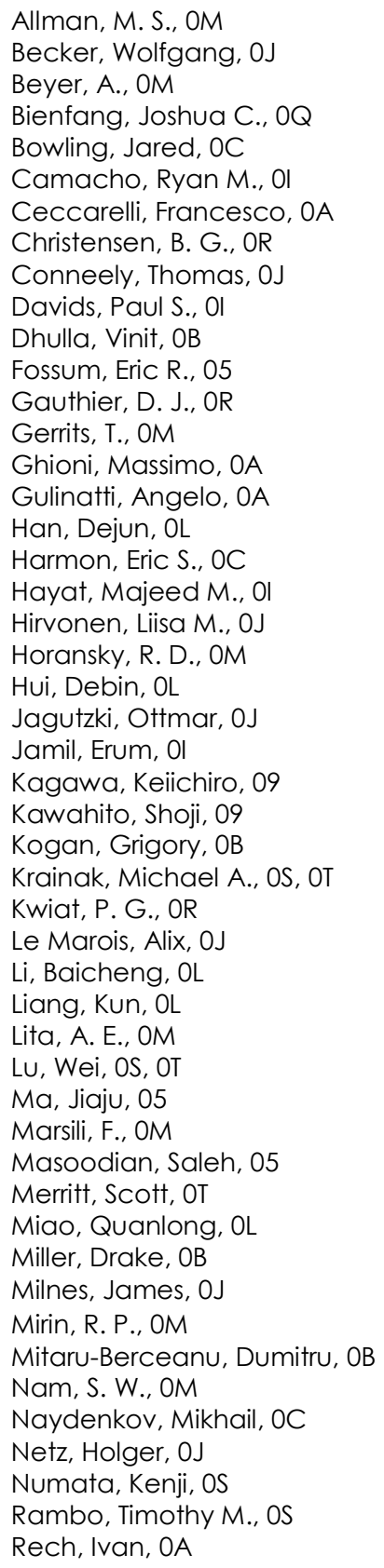

\author{
Restelli, Alessandro, $0 Q$ \\ Seo, Min-Woong, 09 \\ Shaw, M. D., OM \\ Smietana, Stefan, OJ \\ Stern, J. A., OM \\ Stevens, M., OM \\ Stipčević, M., OR \\ Suhling, Klaus, OJ \\ Sun, Xiaoli, OT \\ Verma, V. B., OM \\ Wang, Shenyuan, OL \\ Yang, Guangning, OS, OT \\ Yang, Ru, OL \\ Yasutomi, Keita, 09 \\ Zhao, Tianqi, OL
}


Proc. of SPIE Vol. $9858985801-6$

Downloaded From: https://www.spiedigitallibrary.org/conference-proceedings-of-spie on 26 Apr 2023 Terms of Use: https://www.spiedigitallibrary.org/terms-of-use 


\title{
Conference Committee
}

\author{
Symposium Chair \\ Ming C. Wu, University of California, Berkeley (United States) \\ Symposium Co-chair \\ Majid Rabbani, Eastman Kodak Company (United States) \\ Conference Chair
}

Mark A. Itzler, Princeton Lightwave, Inc. (United States)

Conference Co-chair

Joe C. Campbell, University of Virginia (United States)

Conference Program Committee

Gerald S. Buller, Heriot-Watt University (United Kingdom)

William H. Farr, Jet Propulsion Laboratory (United States)

Robert H. Hadfield, University of Glasgow (United Kingdom)

Majeed Hayat, The University of New Mexico (United States)

Michael A. Krainak, NASA Goddard Space Flight Center (United States)

Robert A. Lamb, SELEX Galileo Ltd. (United Kingdom)

K. Alex McIntosh, MIT Lincoln Laboratory (United States)

Alan L. Migdall, National Institute of Standards and Technology (United States)

Michael Wahl, PicoQuant GmbH (Germany)

Hugo Zbinden, University of Geneva (Switzerland)

Ivan Rech, Politecnico di Milano (Italy)

\section{Session Chairs}

1 Photon-Counting Communications

Mark Itzler, Princeton Lightwave, Inc. (United States)

2 Single-Photon Imaging

Mark Itzler, Princeton Lightwave, Inc. (United States)

3 Single-Photon Avalanche Diode Arrays

Joe C. Campbell, University of Virginia (United States) 
4 Single-Photon Device Integration Platforms

Gerald S. Buller, Heriot-Watt University (United Kingdom)

5 Time-Correlated Single-Photon Counting

Angela Gulinatti, Politecnico di Milano (Italy)

6 Superconducting Nanowire SPDs

William H. Farr, Jet Propulsion Laboratory (United States)

7 Photon-Counting Receivers

Majeed M. Hayat, The University of New Mexico (United States) 